\title{
ANALISIS KONDISI KEUANGAN DITINJAU DARI RASIO LIKUIDITAS, SOLVABILITAS, DAN RENTABILITAS PADA KOPERASI WAHYU DEWATA UTAMA MENGWI, BADUNG
}

\author{
Ni Made Mulia Handayani ${ }^{1}$ \\ I Made Adi Saputra ${ }^{2}$ \\ ${ }^{1,2}$ Fakultas Ekonomi Universitas Ngurah Rai, Denpasar
}

\begin{abstract}
ABSTRAK
Adapun tujuan dari penelitian ini adalah untuk mengetahui kondisi keuangan Koperasi Wahyu Dewata Utama Mengwi, Badung tahun 2014 - 2016. Hasil penelitian menunjukkan bahwa ditinjau dari likuiditas, current rasio, dengan klasifikasi kurang dari 125\% kurang baik. Cash rasio Koperasi Wahyu Dewata Utama Mengwi, Badung tahun 2014 - 2016 dengan klasifikasi kurang dari $30 \%$ kurang baik. Hasil penelitian menunjukkan bahwa ditinjau ROA (Return on Asset), Koperasi Wahyu Dewata Utama Mengwi, Badung tahun 2014 - 2016 dengan klasifikasi lebih besar dari 10\% dengan klasifikasi sangat baik. Rentabilitas Modal Sendiri Koperasi Wahyu Dewata Utama Mengwi, Badung tahun 2014 dengan klasifikasi kurang dari 1\% kurang baik. Tahun 2015 termasuk klasifikasi lebih besar dari 21\% sangat baik. Tahun 2016 dengan klasifikasi lebih dari $10 \%$ baik. Hasil penelitian menunjukkan bahwa ditinjau dari Rasio Modal Sendiri atas Hutang, Koperasi Wahyu Dewata Utama Mengwi, Badung tahun 2014 dengan klasifikasi lebih besar dari 10\% sangat baik, tahun 2015 dengan klasifikasi kurang dari 10\% kurang baik, dan pada tahun 2016 dengan klasifikasi lebih besar dari 10\% cukup baik. Rasio Aktiva Atas Hutang Koperasi Wahyu Dewata Utama Mengwi, Badung tahun 2014 sangat baik lebih besar dari 110\%, tahun 2015 termasuk klasifikasi baik lebih besar dari 101\%, tahun 2016 dengan klasifikasi sangat baik diatas $110 \%$.
\end{abstract}

\section{Kata Kunci : Rasio Likuiditas, Rasio Rentabilitas dan Rasio Solvabilitas}

\section{ABSTRACT}

The purpose of this study is to determine the financial condition of the Wahyu Dewata Utama Mengwi Cooperative, Badung in 2014 - 2016. The results show that in terms of liquidity, current ratio, with a classification of less than $125 \%$ is not good. The cash ratio of Wahyu Dewata Utama Mengwi, Badung in 2014 - 2016 with a classification of less than 30\% is not good. The results showed that in terms of ROA (Return on Asset), Wahyu Dewata Utama Mengwi Cooperative, Badung in 2014 - 2016 with a classification greater than 10\% with very good classification. Profitability of Own Capital Cooperative Wahyu Dewata Utama Mengwi, Badung in 2014 with a classification of less than 1\% is not good. 2015 includes a classification greater than $21 \%$ very good. 2016 with a classification of more than 10\% is good. The results show that in terms of the ratio of Own Capital to Debt, Wahyu Dewata Utama Mengwi Cooperative, Badung in 2014 with a classification greater than 10\% is very good, 2015 with a classification of less than 10\% is not good, and in 2016 with a larger classification. than 10\% is good enough. The ratio of assets to debts of the Wahyu Dewata Utama Mengwi Cooperative, Badung in 2014 was very good, greater than $110 \%$, in 2015 it was classified as good, greater than 101\%, in 2016 with very good classification above $110 \%$.

Keywords : Liquidity Ratios, Profitability Ratios and Solvency Ratios 


\section{PENDAHULUAN}

Koperasi merupakan organisasi ekonomi yang dimiliki dan dioperasikan oleh orang-seorang demi kepentingan bersama untuk mencapai kesejahteraan anggotanya. Koperasi sebagai usaha perekonomian yang berbasis kerakyatan, yang memiliki peran mengembangkan potensi dan kemampuan masyarakat khususnya pada para anggotanya. Untuk kelangsungan kegiatan usaha, koperasi perlu dianalisis kondisi keuangannya untuk mengetahui prospek dan resiko dari kegiatan usaha yang telah dilakukan. Prospek koperasi bisa dilihat dari tingkat keuntungan (profitabilitas) dan risikonya dapat dilihat dari bisa dilihat dari kemungkinan mengalami kesulitan keuangan yang dapat menyebabkan koperasi menjadi bangkrut. Untuk mencegah kebangkrutan menjadi penting artinya untuk selalu mengevaluasi perkembangan kinerja atau kondisi keuangan koperasi.

Kondisi keuangan koperasi penting untuk dievaluasi karena dapat mempengaruhi kelangsungan usaha koperasi secara keseluruhan. Salah satu alat yang dipakai untuk mengevaluasi kondisi keuangan koperasi adalah tingkat kesehatan koperasi yang diambil dari laporan keuangan pada setiap akhir periode yang berisi pertanggungjawaban keuangan atas berjalannya suatu usaha. Laporan keuangan yang diterbitkan koperasi merupakan salah satu sumber informasi mengenai posisi keuangan, kinerja serta perubahan posisi keuangan koperasi, yang sangat berguna untuk mendukung pengambilan keputusan yang tepat.

Laporan keuangan adalah data yang tercermin dalam suatu laporan keuangan yang terdiri dari Neraca, Laporan Rugi Laba serta laporan keuangan lainnya.Dengan melakukan analisis laporan keuangan dari koperasi, akan daiketahui kondisi dan perkembangan keuangan dari koperasi dari waktu kewaktu.Laporan ini nantinya dapat dipakai untuk menyusun rencanakedepan atas kelemahan-kelemahan yang ditemui dari hasil evaluasi. .

Pengukuran tingkat kondisi keuangan koperasi dapat digunakan analisis rasio keuangan (Bambang Riyanto, 2001:35). Dengan menggunakan alat analisis berupa rasio keuangan akan dapat memberi informasi baik atau buruknya posisi keuangan koperasi dari suatu periode ke periode berikutnya. Informasi yang diperoleh dari analisis laporan keuangan diantaranya adalah informasi mengenai likwiditas, rentabilitas dan solvabilitas dari koperasi. Likuiditas merupakan kemampuan koperasi dalam melunasi kewajiban finansial jangka pendek pada saat jatuh tempo dengan menggunakan aktiva lancar yang tersedia. Sedangkan rentabilitas merupakan informasi mengenai kemampuan manajemen dalam mengelola modal yang tertanam dalam koperasi untuk menghasilkan keuntungan, yang merupakan perbandingan antara laba dengan aktiva atau modal yang menghasilkan laba tersebut. Informasi mengenai kemampuan koperasi memenuhi kewajiban jangka panjang maupun jangka pendek terlihat dalam rasio solvabilitas yang merupakan 
perbandingan antara total aktiva dengan total hutang.

Koperasi Wahyu Dewata Utama merupakan salah satu koperasi dari beberapa koperasi yang ada di Kecamatan Mengwi, Kabupaten Badung. Tujuan dari pendirian koperasi ini seperti umumnya tujuan koperasi adalah untuk meningkatkan kesejahteraan anggotanya serta ikut membangun tatanan perekonomian Tabel : 1 Aktiva, Hutang, Modal dan Laba Koperasi Wahyu Dewata Utama di Mengwi, Badung Periode Tahun 2014 s/d Tahun 2016. nasional dalam rangka mewujudkan masyarakat yang maju, adil dan makmur berdasarkan pancasila dan UUD 1945.

Adapun kondisi keuangan pada Koperasi Wahyu Dewata Utama, Mengwi Kabupaten Badung yang bersumber dari laporan keuangannya dari periode tahun 2014 s/d 2016 seperti terlihat pada tabel

\begin{tabular}{ccccc}
\hline \multirow{2}{*}{ TAHUN } & TOTAL & TOTAL & LABA & MODAL \\
& AKTIVA & HUTANG & SEBELUM & \\
& $(\mathrm{RP})$ & $(\mathrm{RP})$ & PAJAK (RP) & SENDIRI (RP) \\
\hline \multirow{2}{*}{2014} & $1.770 .086 .554,90$ & $1.548 .838 .259,07$ & $31.425 .497,30$ & $287.237 .798,53$ \\
& & & & \\
2015 & $3.380 .962 .755,00$ & $3.097 .703 .649,24$ & $63.605 .137,00$ & $219.653 .967,82$ \\
& & & & \\
2016 & $3.861 .997 .369,04$ & $3.502 .342 .423,60$ & $69.577 .357,09$ & $359.577 .588,35$
\end{tabular}

Sumber koperasi wahyu dewata utama mengwi, badung data (diolah)

Berdasarkan tabel 1 terlihat bahwa dari tahun 2014 s/d tahun 2016 total hutang maupun modal sendiri cendrung meningkat. Namun demikian bila dibandingkan pada masing-masing tahun, jumlah total hutang pada Koperasi Wahyu Dewata Utama Mengwi, Badung selalu lebih besar dari jumlah total modal sendiri. Menurut Bambang Riyanto (2001:282), posisi keuangan yang baik adalah nilai modal lebih besar dibandingkan dengan hutang dengan proporsi $40 \%$ hutang dan $60 \%$ modal. Apabila jumlah modal lebih 
dalam penelitian ini bertujuan untuk menganalisis kondisi keuangan Koperasi Wahyu Dewata Utama, Mengwi, Badung dari segi likuiditas, rentabilitas dan solvabilitas dari periode tahun 2014 s/d tahun 2016. Analisis kondisi keuangan berpedoman pada klasifikasi Koperasi berdasarkan pada Keputusan Menteri Negara Koperasi dan Usaha Kecil dan Menengah No : 129/Kep/M /KUKM/XI/2002 tanggal 29 November 2002 (lampiran 12).

\section{Rumusan Masalah}

Berdasarkan latar belakang masalah diatas, maka rumusan masalah dalam penelitian ini adalah : Bagaimana Kondisi Keuangan Koperasi Wahyu Dewata Utama, Mengwi, Kabupaten Badung ditinjau dari segi Likuiditas, Rentabilitas dan Solvabilitas periode tahun 2014 s/d 2016 ?

\section{Tujuan Penelitian}

\begin{tabular}{rrr}
\multicolumn{2}{c}{ Berdasarkan } & rumusan \\
masalah, maka tujuan dalam
\end{tabular} penelitian ini adalah untuk mengetahui kondisi keuangan Koperasi Wahyu Dewata Utama Mengwi, Badung ditinjau dari segi Likuiditas, Rentabilitas dan Solvabilitas periode tahun 2014 s/d 2016.

\section{Kegunaan Penelitian}

Penelitian ini diharapkan dapat memberikan informasi dan referensi bagi pihak-pihak yang berkepentingan khususnya Koperasi Wahyu Dewata Utama Mengwi, Badung sebagai bahan pertimbangan dalam merumuskan kebijakan dalam bidang keuangan.

\section{METODE PENELITIAN}

Penelitian ini dilakukan pada Koperasi Wahyu Dewata Utama, yang belokasi di Mengwi, Badung. Adapun yang menjadi obyek dalam penelitian ini adalah kondisi keuangannya yang dianalisis pada periode tahun 2014 s/d 2016 dilihat dari Likuiditas, Rentabilitas dan Solvabilitas.

\section{PEMBAHASAN}

Kondisi Keuangan Koperasi Wahyu Dewata Utama Mengwi, Badung dinilai dari segi likuiditas, rentabilitas dan solvabilitas dihitung berdasarkan rasio masing - masing kemudian dikomparasikan dengan standar likuiditas, rentabilitas maupun solvabilitas yang ditetapkan dalam Keputusan Menteri Negara Koperasi dan Usaha Kecil dan Menengah Nomor: 129/Kep./M/KUKM/XI/2002 tanggal 29 November 2002 tentang Pedoman Klasifikasi Koperasi. Rasio-rasio dibawah ini digunakan untuk laporan keuangan atas Neraca dan perhitungan perbandingan Hasil Usaha per 31 Desemeber 2016 sebagai dasar mengetahui kesehatan Koperasi Wahyu Dewata Utama antara lain :

\section{Analisis Rasio Likuiditas Untuk Mengukur Kemampuan Koperasi Wahyu Dewata Utama Mengwi, Badung}

Likuiditas adalah kemampuan perusahaan dalam memenuhu kewajiban jangka pendek. Likuiditas Koperasi Wahyu Dewata Utama Mengwi, Badung diukur dengan menggunakan analisis current ratio dan cash ratio. 
a. Curretn Rasio

Rasio ini menunjukkan kemampuan untuk membayar hutang yang segera harus dipenuhi dengan aktiva lancar. Likuiditas Koperasi
Wahyu Dewata Utama Mengwi, Badung dianalisis dengan current ratio tahun 2014-2016 ditunjukkan pada tabel 1 .

Tabel 2 Current Ratio Koperasi Wahyu Dewata Utama Mengwi, Badung Tahun 2014-2016.

\begin{tabular}{cccc}
\hline Tahun & Current Ratio $\%$ & Klasifikasi & Keterangan \\
\hline 2014 & 111,01 & $<125 \%$ & Kurang Baik \\
2015 & 103,09 & $<125 \%$ & Kurang Baik \\
2016 & 104,16 & $<125 \%$ & Kurang Baik \\
\hline
\end{tabular}

Sumber koperasi wahyu dewata utama mengwi, badung data (diolah)

Berdasarkan tabel 2 terlihat bahwa besarnya likuiditas Koperasi Wahyu Dewata Utama Mengwi, Badung pada tahun 2014 dianalisis dengan current ratio adalah sebesar $111,01 \%$. Hal ini berarti bahwa setiap Rp. 1,00 hutang lancar di jamin oleh Rp. 1,11 aktiva lancar. Current ratio pada tahun 2015 sebesar Rp. 103,09\%. Hal ini berarti bahwa setiap Rp. 1,00 hutang lancar dijamin oleh Rp. 1,03 aktiva lancar. Current ratio pada tahun 2016 sebesar 104,16\% berarti bahwa setiap Rp. 1,00 hutang lancar dijamin dengan Rp. 1,04 aktiva lancar.

Jadi berdasarkan data hasil penelitian dari tahun 2014 s/d 2016 setiap tahunnnya diperoleh current ratio berada pada kisaran $111,01 \%$ $104,16 \%$, dimana menurut pedoman klasifikasi koperasi yang ditetapkan dalam Keputusan Menteri Negara Koperasi dan Usaha Kecil dan Menengah Nomor

\section{9/Kep./M/KUKM/XI/2002, current ratio Koperasi Wahyu Dewata Utama Mengwi, Badung termasuk klasifikasi kurang baik.}

b. Cash Ratio menunjukkan kemampuan yang sesungguhnya untuk memenuhi hutang-hutang yang tepat pada waktunya dengan kas yang tersedia dalam perusahaan dan efek yang segera dapat diuangkan. Hasil perhitungan likuiditas Koperasi Wahyu Dewata Utama Mengwi, Badung dianalisis dengan cash ratio tahun 2014 s/d 2016 dibandingkan dengan Keputusan Menteri Negara Koperasi dan Usaha Kecil dan Menengah Nomor: 129/Kep./M/KUKM/XI/2002 tanggal 29 November 2002 tentang Pedoman Klasifikasi Koperasi (lampiran 12), maka 
klasifikasi cash ratio

Koperasi Wahyu Dewata Tabel 3 Cash Ratio Koperasi Wahyu Dewata Utama Mengwi,
Utama Mengwi, Badung ditunjukkan pada tabel 3 .

Badung Tahun 20142016.

\begin{tabular}{cccc}
\hline Tahun & Cash Ratio \% & Klasifikasi & Keterangan \\
\hline 2014 & 28,36 & $<30 \%$ & Kurang Baik \\
2015 & 06,22 & $<30 \%$ & Kurang Baik \\
2016 & 04,53 & $<30 \%$ & Kurang Baik \\
\hline
\end{tabular}

Sumber koperasi wahyu dewata utama mengwi, badung data (diolah)

Berdasarkan Tabel 3 terlihat bahwa besarnya likuiditas Koperasi Wahyu Dewata Utama Mengwi, Badung pada tahun 2014 di analisis dengan cash ratio adalah sebesar 28,36\%. Hal ini berarti bahwa setiap Rp. 1,00 hutang lancar dijamin oleh Rp. 2,83 kas dan efek. Cash ratio pada tahun 2015 sebesar 06,22\%. Hal ini berarti bahwa setiap Rp. 1,00 hutang lancar dijamin oleh Rp. 0,62 kas dan efek. Cash ratio pada tahun 2016 sebesar 04,53\% berarti bahwa setiap Rp. 1,00 hutang lancar dijamin dengan $\mathrm{Rp}$. 0,45 kas dan efek.

Jadi berdasarkan data hasil penelitian yang diperoleh dari tahun 2014 s/d 2016 cash ratio lebih kecil dari 30\% dari tahun 2014 s/d 2016. Dimna menurut pedoman klasifikasi Koperasi yang ditetapkan dalam Keputusan Menteri Negara Koperasi dan Usaha kecil Menengah Nomor : 129/Kep./M/KUKM/XI/2002, cash ratio Koperasi Wahyu Dewata Utama dari tahun 2014 s/d 2016 termasuk dalam klasifikasi kurang baik.

\section{Analisis Rasio Solvabilitas Untuk Mengukur Kemampuan Koperasi Wahyu Dewata Utama}

Solvabilitas adalah kemampuan suatu perusahaan untuk membayar seluruh kewajibannya baik berupa hutang jangka pendek maupun hutang jangka panjang. Solvabilitas Koperasi Wahyu Dewata Utama Mengwi, Badung diukur dengan menggunakan analisis Rasio Modal Sendiri Atas Hutang dan Rasio Aktiva Atas Hutang.

a. Rasio Modal Sendiri Atas Hutang Rasio Modal Sendiri atas Hutang, menggambarkan kemampuan modal pemilik dalam menutupi hutang kepada pihak luar. Hasil perhitungan rasio modal sendiri atas hutang Koperasi Wahyu Dewata Utama Mengwi, Badung periode tahun 2014 s/d tahun 2016, ,kemudian dibandingkan dengan Keputusan Menteri Negara Koperasi dan Usaha Kecil dan Menengah Nomor: 129/Kep./M/KUKM/XI/2002 tanggal 29 November 2002 tentang Pedoman Klasifikasi Koperasi, maka klasifikasi rasio modal sendiri atas hutang Koperasi Wahyu Dewata Utama 
Mengwi, Badung ditunjukkan pada 4

Tabel 4 Rasio Modal

Sendiri atas Hutang Koperasi

\begin{tabular}{cccc}
\hline Tahun & $\begin{array}{c}\text { Rasio Modal Sendiri } \\
\text { atas Hutang }(\%)\end{array}$ & Klasifikasi & Keterangan \\
\hline 2014 & $18,55 \%$ & $<10 \%$ & Sangat Baik \\
2015 & $07,10 \%$ & $<10 \%$ & Kurang Baik \\
2016 & $10,27 \%$ & $<10 \%$ & Cukup Baik \\
\hline
\end{tabular}

Sumber koperasi wahyu dewata utama mengwi, badung data (diolah)

Berdasarkan Tabel 4 terlihat bahwa solvabilitas dengan ratio modal sendiri atas hutang Koperasi Wahyu Dewata Utama Mengwi, Badung tahun 2014 adalah sebesar $18,55 \%$. Hal ini berarti bahwa setiap Rp. 1,00 hutang dijamin dengan Rp. 1,85 modal sendiri. Pada tahun 2015 menunjukkan angka rasio 07,10\% berarti bahwa setiap Rp. 1,00 hutang dijamin dengan Rp. 0,71 modal sendiri. Angka ratio pada tahun 2016 sebesar $10,27 \%$ berarti bahwa setiap Rp. 1,00 hutang dijamin oleh 1,02\% modal sendiri. Pada tahun 2014 rasio modal sendiri atas hutang termasuk klasifikasi sangat baik, sedangkan tahun 2015 termasuk klasifikasi kurang baik, dan pada Tahun 2016 termasuk klasifikasi cukup baik

Jadi berdasarkan data hasil penelitian yang diperoleh, tahun 2014 s/d 2016 rasio modal sendiri atas hutang menunjukkan nilai pada tahun 2014 di atas 10\% dengan klasifikasi sangat baik sedangkan pada tahun 2015 menunjukkan nilai lebih kecil dari 10\% dengan klasifikasi kurang baik dan pada tahun 2016 di atas 10\% dengan klasifikasi cukup baik.
Wahyu Dewata Utama Mengwi, Badung Tahun 2014-2016. 
Tabel 5 Rasio Aktiva atas Hutang Koperasi Wahyu Dewata Utama Mengwi, Badung Tahun 2014-2016.

\begin{tabular}{cccc}
\hline Tahun & $\begin{array}{c}\text { Rasio Aktiva atas } \\
\text { Hutang }(\%)\end{array}$ & Klasifikasi & Keterangan \\
\hline 2014 & 114,43 & $>110 \%$ & Sangat Baik \\
2015 & 109,14 & $>110 \%$ & Baik \\
2016 & 110,27 & $>110 \%$ & Sangat Baik
\end{tabular}

Sumber koperasi wahyu dewata utama mengwi, badung data (diolah)

Berdasarkan Tabel 5 terlihat bahwa solvabilitas dengan ratio Aktiva atas hutang Koperasi Wahyu Dewata Utama Mengwi, Badung tahun 2014 adalah sebesar 114,43 Hal ini berarti bahwa setiap Rp. 1,00 hutang dijamin dengan Rp. 1,14 aktiva. Pada tahun 2015 menunjukkan angka rasio $109,14 \%$ berarti bahwa setiap Rp. 1,00 hutang dijamin dengan Rp. 1,09 aktiva. Angka ratio pada tahun 2016 sebesar $110,27 \%$ berarti bahwa setiap Rp. 1,00 hutang dijamin oleh $1,10 \%$ aktiva.

Jadi berdasarkan data hasil penelitian yang diperoleh dari tahun 2014 termasuk klasifikasi sangat baik lebih besar dari $110 \%$. Pada tahun 2015 termasuk klasifikasi baik lebih besar dari 101\%. Pada tahun 2016, rasio aktiva atas hutang lebih besar dari $110 \%$, dimana menurut pedoman klasifikasi koperasi yang ditetapkan dalam Keputusan Menteri Negara Koperasi dan Usaha Kecil Menengah Nomor 129/Kep./M/KUKM/XI/2002, rasio aktiva atas hutang Koperasi Wahyu Dwata Utama Mengwi, Badung tahun 2016 termasuk dalam klasifikasi sangat baik.

Rasio aktiva atas hutang Koperasi Wahyu Dewata Utama Mengwi, badung tahun 2014 mengalami kenaikan, hal ini disebabkan karena adanya peningkatan aktiva terhadap total hutang yang disebabkan oleh kenaikan jumlah tabungan sukarela dan deposito nasabah yang menurun. Tahun 2015 dan 2016, rasio aktiva atas hutang mengalami penurunan. Penurunan terjadi karena adanya penurunan pada total aktiva yang disebabkan oleh peningkatan jumlah tabungan yang disimpan nasabah kepada koperasi tahun 2015-2016

3. Analisis Rentabilitas Untuk Mengukur Kemampuan Koperasi Wahyu Dewata Utama

Rasio rentabilitas menggambarkan kemampuan perusahaan untuk menghasilkan laba selama periode tertentu. Rentabilitas Koperasi Wahyu Dewata Utama Mengwi, Badung mengukur dengan menggunakan analisis ROA (Return on Asset) dan Rentabilitas Modal Sendiri.

a. ROA (Return on

Asset)/Rentabilitas ekonomis ROA (Return on Asset) mengukur kemampuan manajemen dalam memperoleh laba dari total aktiva yang digunakannya. Hasil perhitungan ROA (Return on Asset) 
Tabel 6 Rasio Laba Sebelum Pajak Dewata Utama Mengwi, Badung atas Total Aktiva Koperasi Wahyu Tahun 2014-2016.

\begin{tabular}{cccc}
\hline Tahun & $\begin{array}{c}\text { ROA }(\text { Return on } \\
\text { Asset })(\%)\end{array}$ & Klasifikasi & Keterangan \\
\hline 2014 & 17,76 & $>10 \%$ & Sangat Baik \\
2015 & 18,81 & $>10 \%$ & Sangat Baik \\
2016 & 18,02 & $>10 \%$ & Sangat Baik \\
\hline
\end{tabular}

Sumber koperasi wahyu dewata utama mengwi, badung data (diolah) Berdarkan tabel 6 terlihat bahwa rentabilitas ekonomis Koperasi Wahyu Dewata Utama Mengwi, Badung tahun 2014 adalah sebesar $17,76 \%$. Hal ini berarti bahwa setiap Rp. 1,00 aktuva menghasilkan laba sebelum pajak sebesar Rp. 0,17. Rentabilitas ekonomis tahun 2015 sebesar $18,81 \%$. Berarti bahwa setiap Rp. 1,00 aktiva menghasikan laba sebelum pajak sebesar Rp. 0,18. Rentabilitas ekonomis tahun 2016 sebesar $18,02 \%$. Hal ini menunjukkan bahwa setiap Rp. 1,00 aktiva menghasikan laba sebelum pajak sebesar Rp. 0,18.

Jika berdasarkan data hasil penelitian yang diperoleh dari tahun 2014 dan 2016, ROA (return on asset)/ rentabilitas ekonomis menunjukkan nilai dibawah $10 \%$, dimana menurut pedoman klasifikasi koperasi yang ditetapkan dalam Keputusan Mentri Negara Koperasi dan Usaha Kecil dan Menengah Nomor 129/Kep./M/KUKM/XI/2002, rentabilitas ekonomis Koperasi Wahyu Dewata Utama Mengwi, Badung termasuk klasifikasi sangat baik. Tahun 2015-2016 mengalami kenaikan, disebabkan oleh adanya penurunan aktiva namun tidak sebanding dengan kenaikan laba sebelum pajak, Aktiva meningkat disebabkan oleh peningkatan kas bank, jumlah pimjaman yang diberikan kepada nasabah dan deposito.

b. Rentabilitas Modal Sendiri

Rentabilitas modal sendiri mengukur kemampuan suatu perusahaan dengan modal sendiri yang bekerja di dalamnya menghasilkan keuntungan. Hasil perhitungan rentabilitas modal sendiri Koperasi Wahyu Dewata Utama Mengwi, Badung periode tahun 2014 s/d 2016 kemudian dibandingkan dengan Keputusan Menteri Negara Koperasi dan Usaha Kecil dan Menengah Nomor:

129/Kep./M/KUKM/XI/2002

tanggal 29 November 2002 tentang Pedoman Klasifikasi Koperasi, maka klasifikasi rentabilitas modal sendiri Koperasi Wahyu Dewata Utama Mengwi, Badung ditunjukkan pada Tabel 7 
Tabel 7 Rentabilitas Modal Sendiri Koperasi Wahyu Dewata Utama Mengwi, Badung 2014 s/d 2016

\begin{tabular}{cccc}
\hline Tahun & $\begin{array}{c}\text { Rentabilitas Modal } \\
\text { sendiri(\%) }\end{array}$ & Klasifikasi & Keterangan \\
\hline 2014 & 09,30 & $<1 \%$ & Kurang Baik \\
2015 & 24,61 & $<1 \%$ & Sangat Baik \\
2016 & 16,45 & $<1 \%$ & Baik
\end{tabular}

Sumber koperasi wahyu dewata utama mengwi, badung data (diolah)

Berdasarkan Tabel 7 menunjukkan selama tiga tahun periode yaitu tahun $2014 \mathrm{~s} / \mathrm{d}$ tahun 2016 besarnya rentabilitas modal sendiri pada Koperasi Wahyu Dewata Utama Mengwi, Badung dengan masing-masing sebesar $09,30 \%, 24,61 \%$ dan $16,45 \%$. Berdasarkan Keputusan Menteri Negara Koperasi dan Usaha Kecil dan Menengah Nomor: 129/Kep./M/KUKM/XI/2002

tanggal 29 November 2002 tentang Pedoman Klasifikasi Koperasi, rentabilitas modal sendiri Koperasi Wahyu Dewata Utama Mengwi, Badung selama periode tahun 2014 besarnya berada pada nilai dibawah $<1 \%$ termasuk klasifikasi kurang baik. Tahu 2015 termasuk klasifikasi sangat baik lebih besar dari > 21\%. Dan pada tahun 2016 termasuk klasifikasi baik lebih dari $10 \%$.
Rentabilitas modal sendiri Koperasi Wahyu Dewata Utama Mengwi, Badung tahun 2014 sebesar 09,30\%, berarti bahwa setiap Rp 1,00 modal sendiri menghasilkan laba setelah pajak sebesar Rp 0,930. Rentabilitas modal sendiri tahun 2015 sebesar $24,61 \%$ berarti bahwa setiap Rp 1,00 modal sendiri menghasilkan laba setelah pajak sebesar Rp 2,461 . Rentabilitas modal sendiri tahun 2016 sebesar 16,45\%, berarti bahwa setiap $\operatorname{Rp} 1,00$ modal sendiri menghasilkan laba setelah pajak sebesar Rp 1,645. Menurunnya rentabilitas modal sendiri pada tahun 2014 dan tahun 2016 disebabkan karena proporsi kenaikan modal sendiri lebih besar dari proporsi kenaikan laba setelah pajak. Modal sendiri meningkat karena peningkatan modal tetap tambahan dan cadangan umum 


\section{Kesimpulan}

Kondisi keuangan Koperasi Wahyu Dewata Utama selama periode tahun 2014 s/d tahun 2016 dari hasil análisis likuiditas, rentabilitas, dan solvabilitas berdasarkan surat Keputusan Menteri Negara Koperasi dan Usaha Kecil dan Menengah

Nomor: 129/Kep./M/KUKM/XI/2002 tanggal 29 November 2002 tentang Pedoman Klasifikasi Koperasi, dapat disimpulkan :

a. Current Ratio Koperasi Wahyu Dewata Utama Mengwi, Badung selama tahun 2014 - 2016 termasuk klasifikasi kurang baik.

b. Cash Ratio Koperasi Wahyu Dewata Utama Mengwi, Badung selama tahun 2014 -2016 termasuk klasifikasi kurang baik.

c. Rasio Modal Sendiri atas Hutang Koperasi Wahyu Dewata Utama Mengwi, Badung selama tahun 2014 termasuk klasifikasi sangat baik, tahun 2015 termasuk klasifikasi kurang baik, dan tahun 2016 termasuk klasifikasi cukup baik.

d. Rasio Aktiva atas Hutang Koperasi Wahyu Dewata Utama Mengwi, Badung selama tahun 2014 dan 2016 termasuk klasifikasi sangat baik. Pada tahun 2015 termasuk klasifikasi baik.

e. Rentabilitas Ekonomis / Return On Asset (ROA) Koperasi Wahyu Dewata Utama Mengwi, Badung selama tahun 2014 - 2016 termasuk klasifikasi sangat baik.

f. Rentabilitas Modal Sendiri Koperasi Wahyu Dewata Utama Mengwi, Badung selama tahun 2014 termasuk klasifikasi kurang baik. Pada tahun 2015 termasuk klasifikasi sangat baik. Dan pada tahun 2016 termasuk klasifikasi baik.

\section{Saran}

Berdasarkan hasil pembahasan dan kesimpulan yang diperoleh, kiranya saran dan masukan yang dapat diberikan untuk Koperasi Wahyu Dewata Utama dalam meningkatkan kondisi keuangan yaitu hendaknya dapat memperbaiki kinerjanya menjadi lebih efektif dan efisien dari yang telah dilakukan sebelumnya, sebagai bahan pertimbangan agar manajemen bisa bekerja lebih efektif dan efisien hendaknya lebih memperhatikan dan memprioritaskan peningkatan di bidang rasio likuiditas, rentabilitas dan solvabilitas sehingga kondisi keuangan menjadi lebih baik.

\section{DAFTAR PUSTAKA}

Alex S. Nitisemito. 2000. Pembelanjaan Perusahaan. Jakarta: Penerbit Ghalia Indonesia.

Arifin, Sitio\&HalomoanTamba. 2001. Koperasi Teori dan Praktik. Jakarta: Erlangga.

Keputusan Menteri Negara Koperasi dan Usaha Kecil dan Menengah Nomor: 129/Kep./M/KUKM/XI/2002 tanggal 29 November 2002 Tentang Pedoman Klasifikasi Koperasi.

Munawir S, 2001. Analisis Laporan Keuangan. Edisi Keempat. Jakarta: Penerbit Liberty.

Rahyuda. 2004. Metodologi Penelitian. Denpasar: Fakultas Ekonomi Universitas Udayana. 
Riyanto, Bambang. 2001. Dasardasar Pembelanjaan Perusahaan. Jakarta: Penerbit BPFE.

Suwardjono. 2003. Akuntansi Pengantar. Yogyakarta : BPFE Yogyakarta.

Sutantya, RH. 2001. Hukum Koperasi Indonesia. Jakarta: Rajawali Pers.

SyafriHarahap, Sofyan. 2001. Analisis Kritis Atas Laporan Keuangan. Jakarta. Penerbit PT. Raja Grafindo Persada.

Soemarso.2004. Akuntansi Suatu Pengantar.Jakarta

:SalembaEmpat.

SyafarudinAlwi, 2002. Alat-alat Analisis Dalam

Pembelanjaan. Jakarta:

Penerbit Fakultas Ekonomi Universitas Islam Indonesia.

Syamsudin,Lukman.2004.Manajeme n Keuangan dan Aplikatifnya Dalam Perencanaan, Pengawasan, dan Pengambilan Keputusan. Bandung.

Widjaja Tunggal, Amin. 2001. Dasardasar Analisis Keuangan. Jakarta: Penerbit Rineka Cipta.

Mamduh M. Hanafi, Abdul Halim. 2009. Analisis Laporan Keuangan. Yogyakarta : Unit Penerbit dan Percetakan Sekolah Tinggi Ilmu Manajemen.

Ikatan Akuntan Indonesia. 2013. Standar Akuntansi Keuangan per 1 Juli 2013. Jakarta: Salemba Empat.
Irham Fahmi. 2011. Analisa Kinerja Keuangan : Panduan bagi Akademisi, Manajer, dan Investor untuk Menilai dan Menganalisis Bisnis dari Aspek Keuangan. Bandung : Alfabeta.

Suma Waka Wiguna.2016. Analisis kondisi keuangan di koperasi Sedana Yoga Desa Bakbakan, Gianyar. Skripsi Fakultas Ekonomi Universitas NgurahRai

Arifin Sitio. 2001. Koperasi Teori dan Praktik. Jakarta : Penerbit Erlangga

Asri Amelia Sihombing.2017. Analisis kondisi keuangan pada Koperasi KPRI XX 2017. yang meneliti likuiditas, rentabilitas dan solvabilitas

Munawir. 2002. Analisa Laporan Keuangan. Yogyakarta : Penerbit UPP-AMP YKPN.

Kasmir. 2010. Pengantar Manajemen Keuangan, Edisi Pertama. Kencana Prenada Media Group. Jakarta.

Riyanto, Bambang. 2004. DasarDasar Pembelanjaan Perusahaan, Edisi Keempat. BPFE UGM. Yogyakarta.

Sutrisno. 2009. Manajemen Keuangan: Teori, Konsep dan Aplikasi, Edisi Pertama. EKONISIA UII. Yogyakarta.

Tika, Moh. Pabundu. 2006. Budaya Organisasi dan Peningkatan Kinerja Perusahaan, Edisi Pertama. PT Bumi Aksara. Jakarta. 